\title{
Kazuistyka/Case report
}

\section{Fizjoterapia po zabiegu endoprotezoplastyki stawu skokowego u pacjenta chorego na hemofilię - opis przypadku}

\section{Physiotherapy after Total Ankle Replacement in a patient with haemophilia - a case study}

\author{
Klaudia Gleb ${ }^{1, *}$, Adam Zawojski ${ }^{2}$, Joanna Zdziarska ${ }^{3}$, Wojciech Szwarczyk ${ }^{4}$ \\ ${ }^{1}$ Zakład Ergonomii i Fizjologii Wysiłku Fizycznego, Wydział Nauk o Zdrowiu, Uniwersytet Jagielloński Collegium \\ Medicum, kierownik: dr hab. n. med. Jan Bilski, Kraków, Polska \\ ${ }^{2}$ Oddział Chirurgii Urazowej, Ortopedii i Rehabilitacji, Krakowskie Centrum Rehabilitacji i Ortopedii, kierownik: \\ dr n. med. Jerzy Jaworski, Kraków, Polska \\ ${ }^{3}$ Klinika Hematologii Szpitala Uniwersyteckiego w Krakowie, kierownik: prof. dr hab. Aleksander Skotnicki, \\ Kraków, Poland \\ ${ }^{4}$ Klinika Rehabilitacji, Wydział Nauk o Zdrowiu, Uniwersytet Jagielloński Collegium Medicum, kierownik: \\ dr n. med. Wojciech Szwarczyk, Kraków, Polska
}

IN F ORMACJE O ARTYKULE

Historia artykułu:

Otrzymano: 18.03.2015

Zaakceptowano: 18.06.2015

Dostępne online: 30.06.2015

Słowa kluczowe:

- hemofilia

- staw skokowy

- fizjoterapia

- rehabilitacja

Keywords:

- Haemophilia

- Ankle joint

- Physiotherapy

- Rehabilitation

\begin{abstract}
A B S T R A C T
Introduction: Haemophilia manifests itself with spontaneous and posttraumatic bleeds, most often to joints, muscles, viscera and Central Nervous System (CNS), causing degenerative changes. Advanced arthropathy of the ankle joint occurs even in young adults with haemophilia. The aim of this study was to present the physiotherapy process and its effect after Total Ankle Replacement (TAR) of the ankle joint in a patient with haemophilia. Material and methods: A 42-year-old patient with moderate haemophilia $\mathrm{B}$ after total ankle replacement of the ankle joint attended physiotherapy in a day-care ward setting. The AOFAS Scale (American Orthopaedic Foot and Ankle Society anklehindfoot scale) has been used to assess the effectiveness of the treatment, VAS scale (Visual Analog Scale) to assess level of pain, TUG test (Timed Up and Go) to assess dynamic and static balance, the range of motion in the ankle joint was measured using goniometer and the muscle strength was assessed with using Lovett scale. Conclusions: Function of the ankle joint significantly improved, the level of pain decreased and time needed to complete the TUG test shortened. The range of motion as well as strength of the muscles acting on the ankle joint improved slightly.
\end{abstract}

(C) 2015 Polskie Towarzystwo Hematologów i Transfuzjologów, Instytut Hematologii i Transfuzjologii. Published by Elsevier Sp. z o.o. All rights reserved.

\footnotetext{
* Autor do korespondencji: Zakład Ergonomii i Fizjologii Wysiłku Fizycznego Instytut Fizjoterapii Uniwersytet Jagielloński Collegium Medicum, ul. Grzegórzecka 20, 31-531 Kraków, Polska. Tel.: +48 124219351.

Adres email: klaudia.gleb@gmail.com (K. Gleb).

http://dx.doi.org/10.1016/j.achaem.2015.06.001

0001-5814/@ 2015 Polskie Towarzystwo Hematologów i Transfuzjologów, Instytut Hematologii i Transfuzjologii. Published by Elsevier Sp. $\mathrm{z}$ o.o. All rights reserved.
} 


\section{Wstęp}

Hemofilia jest rzadką chorobą dziedziczną, sprzężoną z chromosomem X. Niedobór czynnika krzepnięcia (VIII w hemofilii typu A, IX w hemofilii typu B) sprawia, że czop płytkowy, powstający w konsekwencji uszkodzenia tkanek, nie jest wystarczająco wzmocniony fibryną, czego skutkiem jest nadmierna tendencja do krwawień. Wyróżnia się trzy postacie hemofilii: ciężką (aktywność czynnika VIII lub IX poniżej 1\% normy), umiarkowaną (aktywność czynnika VIII lub IX w przedziale 1-5\% normy) i łagodną (aktywność czynnika VIII lub IX >5-50\% normy) [1].

Klinicznie hemofilia objawia się spontanicznymi lub pourazowymi wylewami krwi, najczęściej do stawów, mięśni, narządów wewnętrznych i centralnego układu nerwowego (CUN) [2]. W wyniku krwawień dostawowych dochodzi do rozwinięcia się artropatii hemofilowej. Krew znajdująca się w stawie wywołuje stan zapalny błony maziowej, który z kolei przyczynia się do wystąpienia kolejnych wylewów jest to tak zwane błędne koło (vicious cycle) [3]. Jednocześnie zmiany w obrębie narządu ruchu stanowią główną przyczynę niepełnosprawności osób chorych na hemofilię [4].

Zaawansowane zmiany zwyrodnieniowe stawu skokowego występują już u młodych dorosłych chorych na ciężką, a niekiedy również umiarkowaną postać hemofilii. Pierwsze krwawienia dostawowe pojawiają się zazwyczaj wtedy, gdy dziecko uczy się chodzić. Powtarzające się wielokrotnie na przestrzeni lat doprowadzają do nieodwracalnych zmian w strukturach stawowych [5]. W badaniu przedmiotowym stawu skokowego obserwuje się znaczne ograniczenie (aż do całkowitego braku) zgięcia podeszwowego i grzbietowego, co wynika ze zmian w stawie skokowym górnym. Procesy degeneracyjne obejmują również staw skokowy dolny (staw skokowo-piętowy, staw skokowo-piętowo-łódkowy), utrudniając bądź uniemożliwiając ruchy inwersji/ewersji i pronacji/supinacji. Dodatkowo kość piętowa często występuje w ustawieniu szpotawym (varus) w stosunku do kości skokowej, co z kolei skutkuje rotacją w kierunku koślawości (valgus) w stawie skokowym górnym [6].

Zmiany degeneracyjne w stawie skokowym mają znaczący wpływ na jakość życia chorego nie tylko ze względu na ograniczenia funkcjonalne nimi spowodowane, ale przede wszystkim ból, który ostatecznie przypieczętowuje decyzję o wykonaniu zabiegu chirurgicznego [6]. Gdy leczenie nieoperacyjne (farmakologiczne, rehabilitacja) bądź chirurgiczne (artroskopowe/otwarte oczyszczenie stawu, osteotomia korekcyjna nadkostkowa - supramalleolar oosteotomy for realignment) nie przynoszą spodziewanych efektów, rozważa się wykonanie artrodezy stawu skokowego (ankle fusion; AF) bądź endoprotezoplastyki (Total Ankle Replacement; TAR) [7-10].

Proteza stawu skokowego składa się z elementów metalowych: piszczelowego i skokowego oraz znajdującej się między nimi wkładki polietylenowej (Ryc. 1). W trakcie operacji możliwy jest odpowiedni dobór rozmiaru tych elementów i ich osadzenie w miejsce przyciętych końców stawowych kości piszczelowej i skokowej [11, 12].

Celem pracy było przedstawienie wpływu postępowania fizjoterapeutycznego na możliwości funkcjonalne pacjenta, ból w stawie skokowym, ogólną mobilność, równowagę
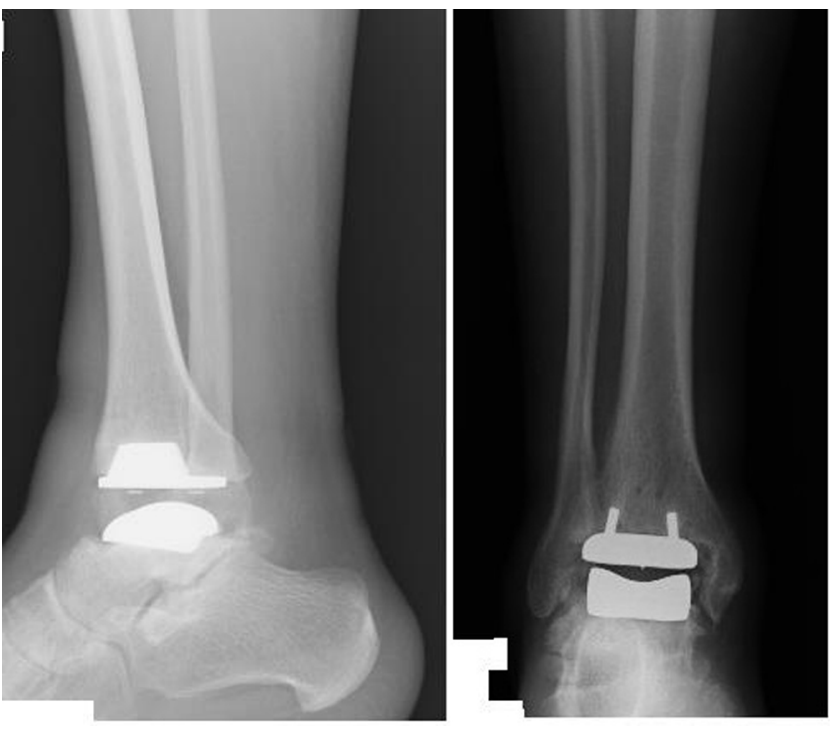

Ryc. 1 - Zdjęcie RTG boczne i a-p stawu skokowego po zabiegu TAR

Fig. 1 - Ankle joint X-ray: side view and PA (Posterior to Anterior) after TAR

statyczną i dynamiczną, zakres ruchomości w stawie skokowym oraz siłę mięśni działających na ten staw u pacjenta chorego na hemofilię, u którego wykonano zabieg endoprotezoplastyki.

\section{Material i metody}

42-letni pacjent z umiarkowaną postacią hemofilii B (aktywność czynnika IX 1,2\%), 10 tygodni po zabiegu alloplastyki stawu skokowego prawego (04.2014) został przyjęty do oddziału dziennego rehabilitacji celem usprawniania. Pacjent poza okresami profilaktyki pooperacyjnej był leczony koncentratami czynnika IX w schemacie „na żądanie” (w dzieciństwie osoczem świeżo mrożonym). Przebył liczne krwawienia do dużych stawów, które doprowadziły do artropatii stawów skokowych, kolanowych, biodrowych oraz łokciowych. W 2010 r. wykonano u niego zabieg alloplastyki stawu biodrowego prawego, a w 2012 r. stawu kolanowego prawego. Nie cierpiał na inne choroby poza kamicą nerkową. Przebył cholecystektomię laparoskopową 8 lat wcześniej oraz skuteczne leczenie przewlekłego zapalenia wątroby typu C 6 lat wcześniej.

Pacjent poruszał się za pomocą dwóch kul łokciowych. Stwierdzono nieprawidłowy wzorzec chodu: brak kontaktu pięty prawej z podłożem w związku z przykurczem zgięciowym w stawie biodrowym prawym, przykurczem zgięciowym oraz szpotawością kolana prawego, a także skróceniem prawego ścięgna Achillesa, brak fazy przetoczenia stopy oraz odbicia. Czas trwania fazy podporu na stopie prawej był znacznie krótszy w stosunku do stopy lewej. Chód określono jako zapadający, ze względu na skrócenie czynnościowe kończyny dolnej prawej. Pacjent sygnalizował znaczną bolesność po stronie bocznej stawu skokowego prawego podczas fazy podporu, w konsekwencji czego 
Tabela I - Wyniki badania ortopedycznego na różnych etapach procesu rehabilitacji

Table I - Results of the orthopaedic examination on various stages of rehabilitation process

\begin{tabular}{|c|c|c|c|}
\hline Rodzaj badania & $\begin{array}{l}\text { Przed rozpoczęciem } \\
\text { rehabilitacji }\end{array}$ & $\begin{array}{l}\text { Po } 1 \text { turnusie } \\
\text { rehabilitacyjnym }\end{array}$ & $\begin{array}{l}\text { Po } 2 \text { turnusie } \\
\text { rehabilitacyjnym }\end{array}$ \\
\hline Ból mierzony za pomocą skali VAS & 7 & 7 & 5 \\
\hline $\begin{array}{l}\text { Czas (mierzony w sekundach) w teście Timed Up and Go } \\
\text { (TUG) }\end{array}$ & 17,6 & 16,68 & 11,23 \\
\hline $\begin{array}{l}\text { Zgięcie w stawie kolanowym (w stopniach, mierzone } \\
\text { goniometrem) }\end{array}$ & 87 & 90 & 93 \\
\hline $\begin{array}{l}\text { Wyprost w stawie kolanowym (w stopniach, mierzone } \\
\text { goniometrem) }\end{array}$ & -20 & -15 & -12 \\
\hline Zgięcie grzbietowe (w stopniach, mierzone goniometrem) & 1 & 2 & 3 \\
\hline $\begin{array}{l}\text { Zgięcie podeszwowe (w stopniach, mierzone } \\
\text { goniometrem) }\end{array}$ & 3 & 5 & 5 \\
\hline Ewersja/inwersja (w stopniach, mierzone goniometrem) & Brak ruchu & Brak ruchu & Brak ruchu \\
\hline Pronacja/supinacja (w stopniach, mierzone goniometrem) & Brak ruchu & Brak ruchu & Brak ruchu \\
\hline $\begin{array}{l}\text { Siła mięśni prostowników stawu kolanowego mierzona za } \\
\text { pomocą skali Lovetta }\end{array}$ & 5 & 5 & 5 \\
\hline Siła mięśni zginaczy stawu kolanowego (skala Lovetta) & +4 & +4 & +4 \\
\hline $\begin{array}{l}\text { Siła mięśni zginaczy podeszwowych stawu skokowego } \\
\text { (skala Lovetta) }\end{array}$ & 1 & 2 & 2 \\
\hline $\begin{array}{l}\text { Siła mięśni zginaczy grzbietowych stawu skokowego } \\
\text { (skala Lovetta) }\end{array}$ & 1 & 2 & 2 \\
\hline $\begin{array}{l}\text { Siła mięśni pronatorów stawu skokowego - mięśnie } \\
\text { strzałkowe (skala Lovetta) }\end{array}$ & $\begin{array}{l}\text { Skurcz mięśnia } \\
\text { niezauważalny }\end{array}$ & $\begin{array}{l}\text { Skurcz mięśnia } \\
\text { niezauważalny }\end{array}$ & $\begin{array}{l}\text { Skurcz mięśnia } \\
\text { niezauważalny }\end{array}$ \\
\hline $\begin{array}{l}\text { Siła mięśni supinatorów stawu skokowego - mięśnie } \\
\text { piszczelowe (skala Lovetta) }\end{array}$ & $\begin{array}{l}\text { Skurcz mięśnia } \\
\text { niezauważalny }\end{array}$ & $\begin{array}{l}\text { Skurcz mięśnia } \\
\text { niezauważalny }\end{array}$ & $\begin{array}{l}\text { Skurcz mięśnia } \\
\text { niezauważalny }\end{array}$ \\
\hline
\end{tabular}

bardziej obciążał boczny brzeg stopy (bierny ruch pronacji również był bolesny). Po dłuższym przebywaniu w pozycji siedzącej bądź leżącej pacjent zgłaszał brak możliwości natychmiastowego obciążenia prawej stopy - aby chód był możliwy, konieczne było stopniowanie obciążania. W teście timed up and go (TUG) [13] pacjent uzyskał wynik wskazujący na obniżenie sprawności fizycznej (Tab. I). Zakresy ruchów w stawie skokowym oraz ocenę siły mięśni działających na staw skokowy zawarto w tabeli I. Zaawansowanie zmian
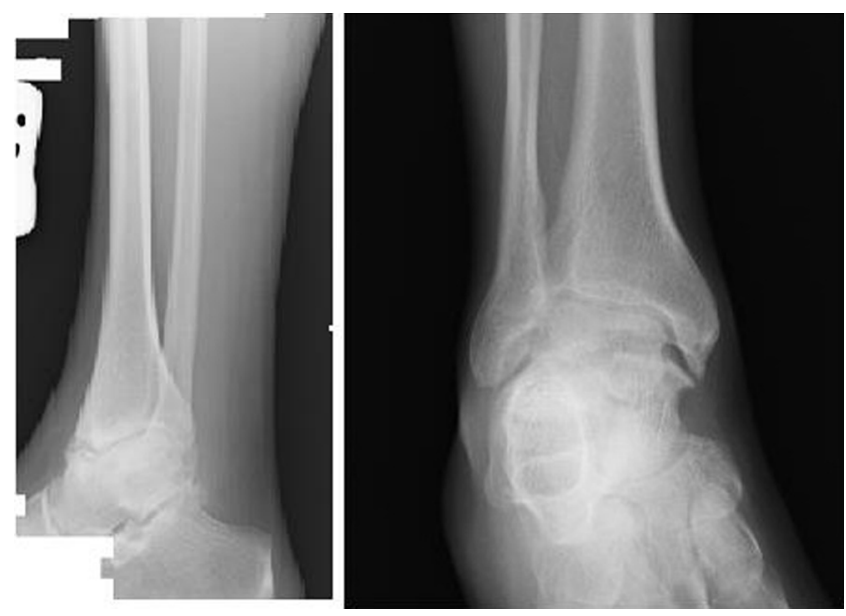

Ryc. 2 - Zdjęcie RTG boczne i a-p stawu skokowego przed zabiegiem TAR

Fig. 2 - Ankle joint X-ray: side view and PA (Posterior to Anterior) before TAR artropatycznych w stawie skokowym oceniono za pomocą skali Petterssona na 12 punktów (Ryc. 2).

\section{Opis procesu usprawniania}

Po przeprowadzeniu szczegółowego badania ortopedycznego oraz ustaleniu wspólnego dla pacjenta i terapeuty celu rehabilitacji rozpoczęto proces usprawniania, którego charakterystykę przedstawiono w tabeli II. Pacjent uczestniczył w rehabilitacji 3 razy w tygodniu przez 5 tygodni, przy czym czas trwania jednej sesji wynosił 1,5 godziny. Po 4 tygodniach przerwy cykl powtórzono (ponownie 3 razy w tygodniu przez okres 5 tygodni). W trakcie każdej sesji rehabilitacji pacjent podawał sobie koncentrat czynnika IX w schemacie profilaktycznym, w dawce $27-40 \mathrm{j} / \mathrm{kg}$ co 2 dni. Nie obserwowano w tym czasie krwawień do stawów ani innych powikłań krwotocznych.

Po zakończeniu pierwszej serii zabiegów ponownie przeprowadzono badanie ortopedyczne, którego wyniki zaprezentowano w tabeli I. Po upływie 15 tygodni od zabiegu endoprotezoplastyki pacjent odrzucił jedną kulę. Po 16 tygodniach od zabiegu podjął próbę poruszania się bez kul po płaskim i równym terenie, jednakże przejście dłuższego dystansu $(500 \mathrm{~m})$ powodowało znaczny dyskomfort spowodowany bólem.

W 20 tygodniu po zabiegu operacyjnym rozpoczęto drugą sesję rehabilitacyjną, która, podobnie jak poprzednio, odbywała się 3 razy w tygodniu i trwała od 1,5 do 2 godzin. W dalszym ciągu stosowano mobilizację blizny pooperacyjnej (Ryc. 3), mobilizację ścięgna Achillesa (Ryc. 4, 5) oraz techniki manualne (Ryc. 6, 7, 8) w celu zwiększenia zakresu 
Tabela II - Procedury wykonywane podczas procesu rehabilitacji

Table II - Procedures executed during the rehabilitation process

\begin{tabular}{|c|c|}
\hline Procedura & Charakterystyka wykonanej procedury \\
\hline $\begin{array}{l}\text { Mobilizacja blizny } \\
\text { pooperacyjnej }\end{array}$ & Podłużne, poprzeczne oraz skośne rozciąganie tkanek wokół blizny \\
\hline $\begin{array}{l}\text { Mobilizacja stawu } \\
\text { skokowego }\end{array}$ & $\begin{array}{l}\text { Wykorzystanie technik terapii manualnej w celu zwiększenia zakresu ruchów zgięcia podeszwowego i } \\
\text { grzbietowego, pronacji, supinacji }\end{array}$ \\
\hline $\begin{array}{l}\text { Mobilizacja ścięgna } \\
\text { Achillesa }\end{array}$ & Rozciąganie, rozcieranie i przełamywanie \\
\hline $\begin{array}{l}\text { Rozciąganie mięśnia } \\
\text { trójgłowego łydki }\end{array}$ & $\begin{array}{l}\text { Pacjent w leżeniu przodem, kończyna dolna zgięta w stawie kolanowym do } 45^{\circ} \text {. Terapeuta lewą ręką prostuje } \\
\text { nogę, pacjent ten ruch oporuje, terapeuta prawą ręką biernie rozciąga mięsień trójgłowy łydki, począwszy do } \\
\text { ścięgna Achillesa w stronę dołu podkolanowego }\end{array}$ \\
\hline Rowerek treningowy & Czas trwania 10 minut, bez obciążenia \\
\hline Orbitrek & Czas trwania 10 minut \\
\hline $\begin{array}{c}\text { Ćwiczenia na dyskach } \\
\text { sensomotorycznych }\end{array}$ & $\begin{array}{l}\text { Ćwiczenia równowagi, koordynacji, propriocepcji, a także zwiększające zakres ruchomości w stawie skokowym } \\
\text { (zgięcie grzbietowe i podeszwowe, pronację i supinację). Ćwiczenia te można również wykonywać z } \\
\text { wyłączeniem kontroli wzrokowej }\end{array}$ \\
\hline Ćwiczenia izometryczne & Z wykorzystaniem taśmy Thera Band - oporowanie zgięcia podeszwowego i grzbietowego \\
\hline Ćwiczenia czynne & $\begin{array}{l}\text { Ćwiczenia z wykorzystaniem przyborów (piłka o średnicy } 65 \mathrm{~cm} \text {, taśma TRX) w celu wzmocnienia mięśni } \\
\text { kończyn dolnych }\end{array}$ \\
\hline $\begin{array}{l}\text { Relaksacja } \\
\text { poizometryczna }\end{array}$ & Próba zwiększenia zakresu zgięcia i zmniejszenia przykurczu zgięciowego w stawie biodrowym i kolanowym \\
\hline $\begin{array}{l}\text { Reedukacja prawidłowego } \\
\text { wzorca chodu }\end{array}$ & $\begin{array}{l}\text { Z wykorzystaniem poręczy, kijków do nordic walking, nauka wchodzenia i schodzenia ze schodów, chodzenie } \\
\text { tyłem }\end{array}$ \\
\hline
\end{tabular}

ruchomości w stawie skokowym, a także relaksację poizometryczną, której celem było uzyskanie poprawy zakresu ruchomości w stawie kolanowym. Dodatkowo rozpoczęto trening chodu bez kul (Ryc. 10), na dystansach dłuższych niż $1 \mathrm{~km}$ pacjent używał 1 kuli łokciowej. Niestety, ze względu na utrzymujący się przykurcz zgięciowy w stawie kolanowym oraz przykurcz zgięciowy w stawie biodrowym, niemożliwe było uzyskanie poprawy w zakresie poszczególnych faz chodu. Wyeliminowanie bólu po stronie bocznej stawu skokowego pozwoliło pacjentowi na obciążanie całej powierzchni podeszwowej stopy, a czas obciążenia zrównał się z czasem obciążenia stopy lewej. Kontynuowano ćwiczenia równowagi i propriocepcji z wykorzystaniem dysków sensomotorycznych (Ryc. 9), a także ćwiczenia wzmacniające mięśnie kończyn

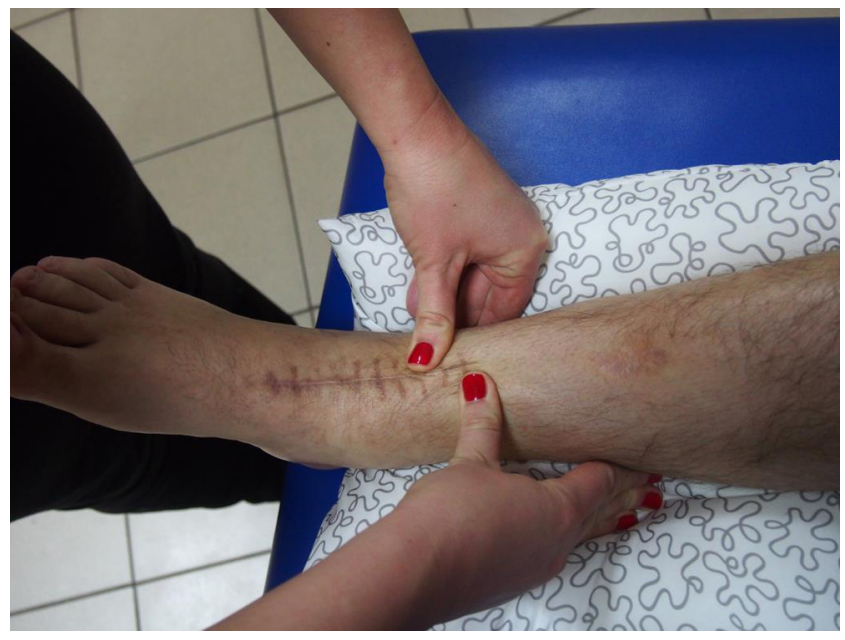

Ryc. 3 - Mobilizacja blizny pooperacyjnej Fig. 3 - Mobilization of the post-operative scar dolnych i ćwiczenia czynne wolne (Ryc. 11, 12). Uzyskane wyniki przedstawiono w tabeli I.

Po zakończeniu drugiej sesji rehabilitacji pacjent poruszał się bez kul na dystansie $>500 \mathrm{~m}$, bez dolegliwości bólowych. Mógł powrócić do wykonywania pracy zawodowej (praca umysłowo-fizyczna), choć wielogodzinne przebywanie w pozycji stojącej wywoływało obrzęk w okolicy stawu skokowego oraz dyskomfort spowodowany bólem (VAS- 5).

\section{Wyniki i omówienie}

Nawracające krwawienia w obrębie stawu skokowego $\mathrm{u}$ chorych na hemofilię prowadzą do przewlekłego zapalenia

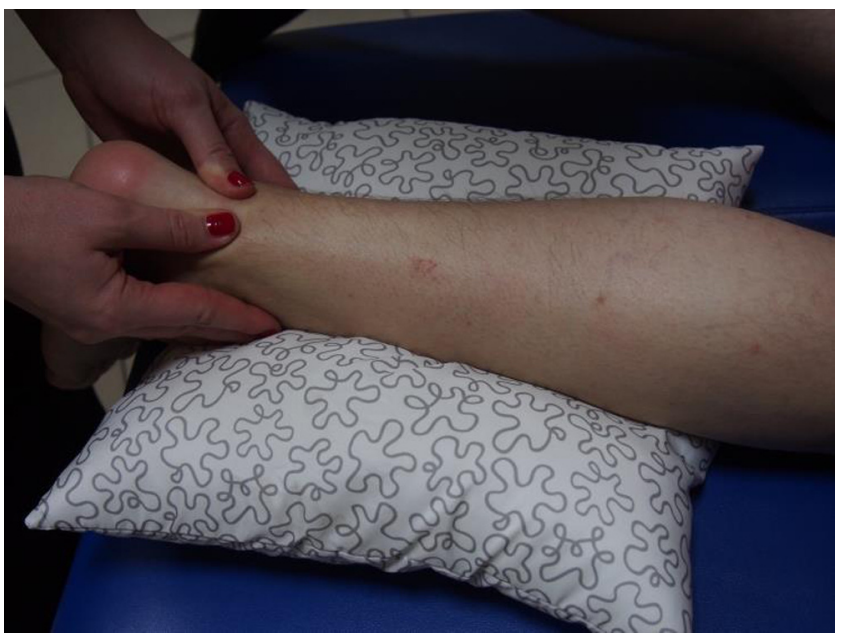

Ryc. 4 - Mobilizacja ścięgna Achillesa Fig. 4 - Mobilization of the Achilles tendon 


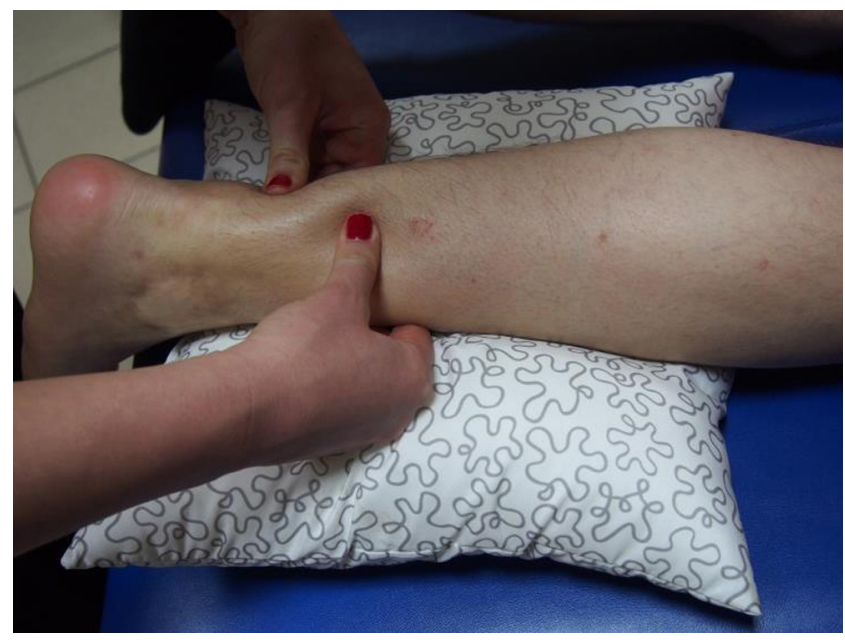

Ryc. 5 - Mobilizacja ścięgna Achillesa

Fig. 5 - Mobilization of the Achilles tendon

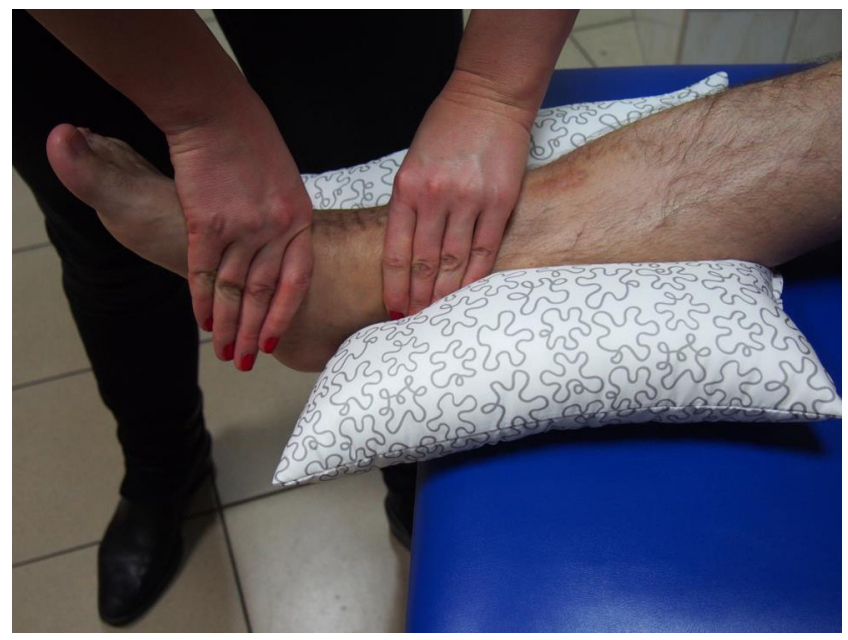

Ryc. 6 - Mobilizacja stawu skokowego

Fig. 6 - Mobilization of the ankle joint

błony maziowej, jej przerostu i neowaskularyzacji, co $\mathrm{w}$ mechanizmie tak zwanego błędnego koła (vicious cycle) doprowadza do ponownych wylewów [10, 14]. Odkąd koncentraty czynników krzepnięcia stały się w Polsce dostępne, pojawiła się możliwość leczenia domowego (początkowo w schemacie na żądanie, $\mathrm{z}$ biegiem czasu również profilaktycznego). Od 2008 roku u dzieci z ciężką postacią hemofilii A i B stosuje się profilaktykę pierwotną, co oznacza, że tak poważne konsekwencje hemofilii, jakie obserwujemy u chorych urodzonych przed 2008 rokiem, nie będą już występować. Profilaktyka wtórna u wszystkich chorych na hemofilię o ciężkim przebiegu klinicznym jest możliwa dopiero od 2014 roku [15], stąd nawet u młodych dorosłych stwierdza się znaczne zmiany zwyrodnieniowe stawów, wymagające leczenia operacyjnego.

Leczenie chirurgiczne zaawansowanych zmian zwyrodnieniowych stawu skokowego w głównej mierze opiera się na jego usztywnieniu lub zastąpieniu elementami protezy. Literatura dotycząca artrodezy i alloplastyki stawu skokowego

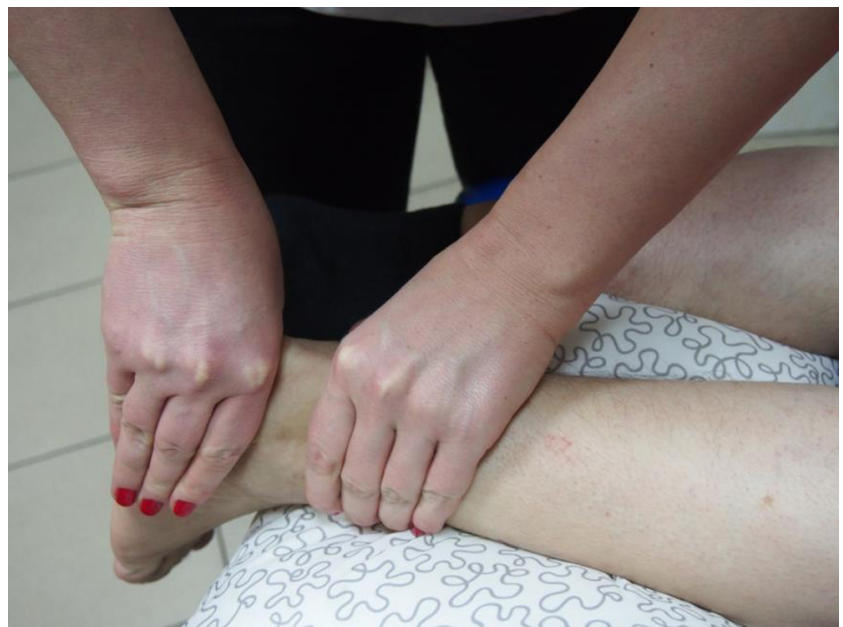

Ryc. 7 - Mobilizacja stawu skokowego

Fig. 7 - Mobilization of the ankle joint

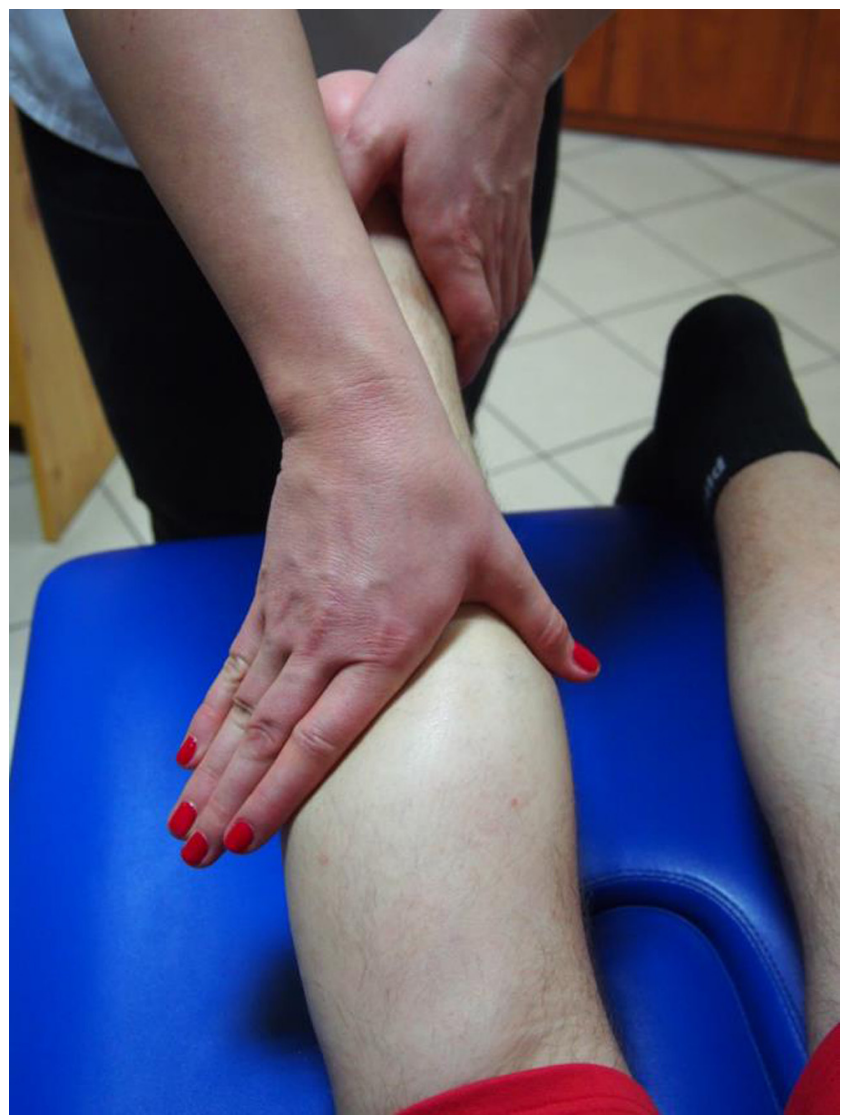

Ryc. 8 - Rozciąganie mięśnia trójgłowego łydki

Fig. 8 - Stretching of the triceps of the calf

u chorych na hemofilię jest ograniczona, dotyczy niewielkiej liczby pacjentów, a czas obserwacji z reguły był krótki. Dyskusja, która z tych metod jest bardziej efektywna, wciąż pozostaje otwarta $[7,16]$. Wydaje się, że zajmowane stanowisko w kwestii przewagi jednego leczenia nad drugim wynika z doświadczeń własnych autorów. 


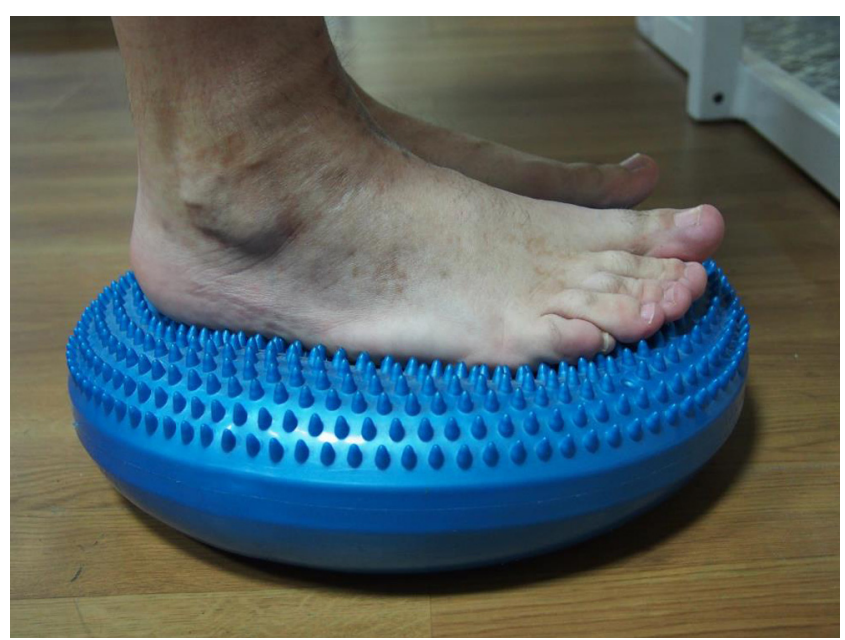

Ryc. 9 - Ćwiczenia na dysku sensomotorycznym

Fig. 9 - Exercises on the sensomotoric disc

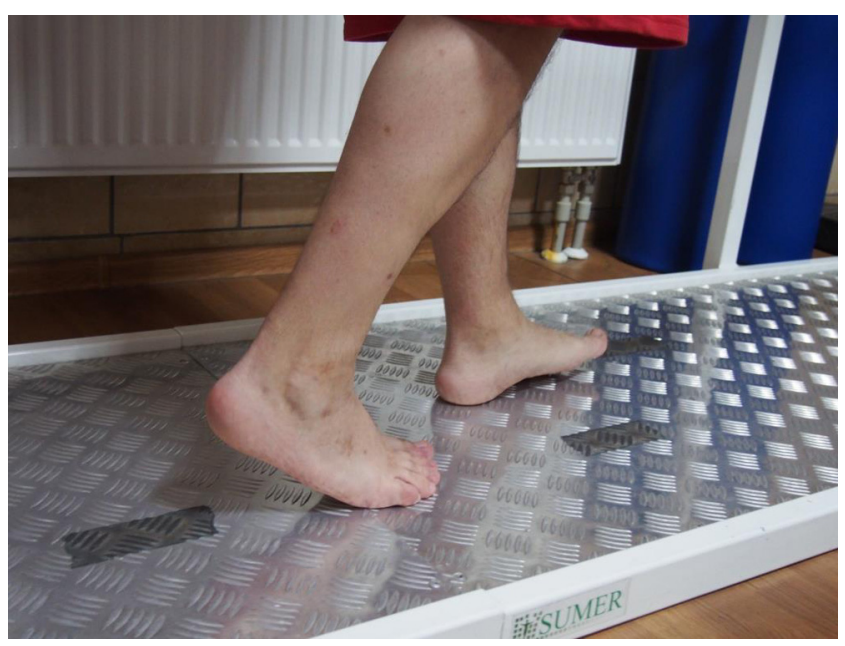

Ryc. 10 - Reedukacja prawidłowego wzorca chodu

Fig. 10 - Re-education of the correct pattern of the walk

Uzyskane wyniki rehabilitacji w opisywanym przypadku pacjenta wskazują na poprawę możliwości funkcjonalnych, redukcję bólu oraz nieznaczną poprawę zakresu ruchomości w stawie skokowym. Niemożliwe jest porównanie tych wyników z innymi doniesieniami, ponieważ, według wiedzy autorów, kwestia ta nie była dotąd poruszana w literaturze. W badaniu przeprowadzonym przez Strauss i wsp. opisano rezultat 11 TAR u 10 pacjentów, z których 8 miało postać ciężką hemofilii, 2 umiarkowaną [10]. Celem badania była ocena efektów alloplastyki stawu skokowego w krótkim i nieco dłuższym okresie po zabiegu u pacjentów w końcowym stadium artropatii hemofilowej i ze współistniejącym nosicielstwem wirusa zapalenia wątroby typu C i wirusa HIV. Zarówno AOFAS score, jak i nasilenie bólu w skali VAS uległy istotnej statystycznie poprawie, co przełożyło się na pozytywną ocenę przez pacjentów własnego stanu zdrowia. Poprawa zakresu ruchu w stawie (ROM) nie była statystycznie istotna. Podobne wyniki przedstawili Barg i wsp. [17]. Celem pracy była ocena niezbyt odległych

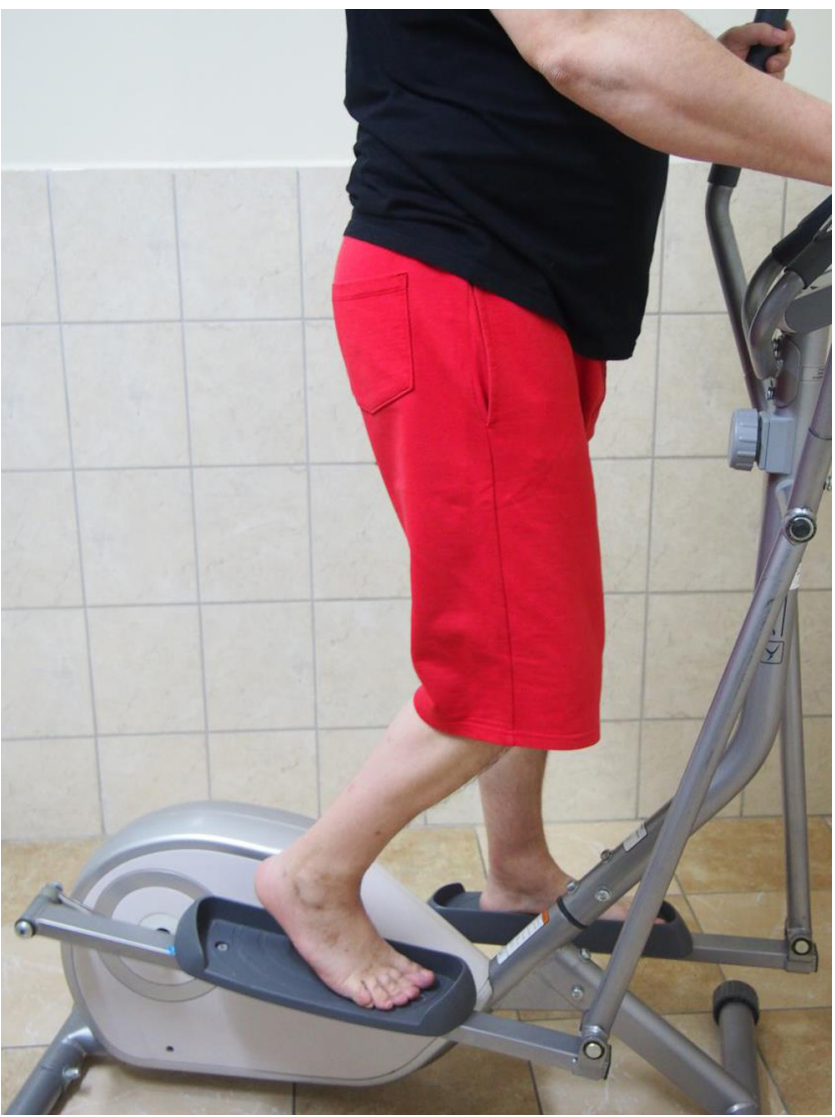

Ryc. 11 - Ćwiczenia czynne w zamkniętym łańcuchu kinematycznym

Fig. 11 - Active exercises in the closed kinematic chain

efektów alloplastyki stawu skokowego przy użyciu protezy składającej się z trzech elementów. Wykonano 10 zabiegów TAR u 8 pacjentów, a czas obserwacji po zabiegu wyniósł średnio 5,6 roku. Do oceny przed zabiegiem i monitorowania postępów po zabiegu wykorzystano skalę AOFAS, w której wykazano znaczną poprawę ze średnio 38 punktów do 81 . Wszyscy pacjenci byli zadowoleni z efektów zabiegu, 4 całkowicie uwolniło się od bólu. Średni poziom bólu u wszystkich pacjentów biorących udział w badaniu zmniejszył się z 7,1 do $0,8 \mathrm{w}$ skali VAS. We wszystkich kategoriach kwestionariusza SF-36 uzyskano istotną poprawę. Poprawa zakresu ruchomości była niewielka i nieistotna statystycznie. Uzyskane wyniki pozwoliły autorom wysunąć wniosek, że całkowita alloplastyka stawu skokowego jest dobrą alternatywą dla artrodezy.

Niewielka poprawa zakresu ruchomości występuje także po zabiegach TAR u pacjentów operowanych $z$ przyczyn innych niż artropatia hemofilowa (zmiany zwyrodnieniowe, pourazowe i reumatyczne), co wynika z przeglądu systematycznego przeprowadzonego przez Gougoulias i wsp. [18]. Strauss i wsp. [10] wysuwają przypuszczenie, że za niewielką poprawę ROM (lub jego brak) u chorych na hemofilię może odpowiadać stan zapalny błony maziowej oraz bliznowacenie torebki stawowej wywołane powtarzającymi się krwawieniami do jamy stawu. 


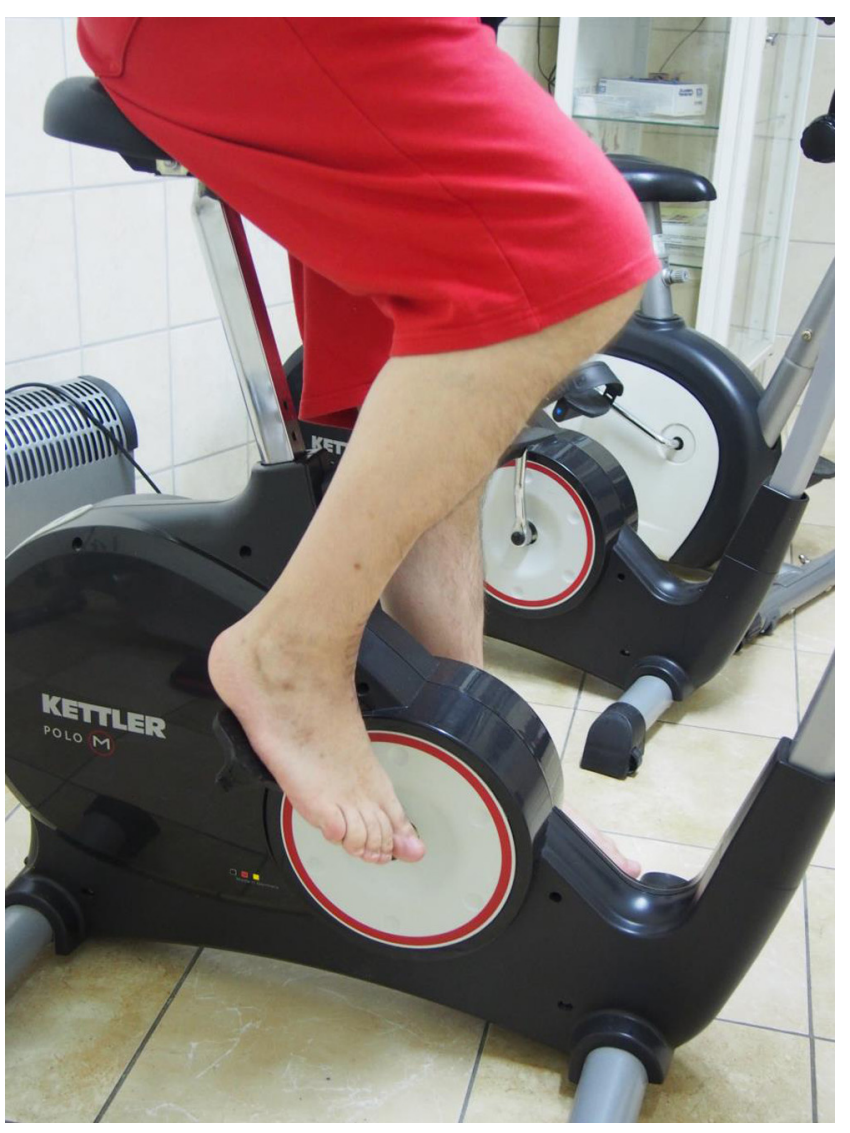

Ryc. 12 - Ćwiczenia czynne w zamkniętym lańcuchu kinematycznym

Fig. 12 - Active exercises in the closed kinematic chain

Artrodeza jest postępowaniem $\mathrm{z}$ wyboru $\mathrm{u}$ pacjentów z zaawansowanymi zmianami zwyrodnieniowymi w stawie skokowym [8, 19-24]. W swoim badaniu Bluth i wsp. uwzględnili największą $\mathrm{z}$ dotychczas opisanych grup pacjentów $\mathrm{z}$ hemofilią $\mathrm{z}$ najdłuższym czasem obserwacji, u których wykonano zabieg usztywnienia stawu skokowego. W badaniu wzięło udział 45 pacjentów (57 artrodez), średni czas obserwacji wyniósł 6,6 roku. Nie odnotowano śródoperacyjnych ani pooperacyjnych powikłań. Badanie skalą AOFAS wykazało całkowity brak bólu u 75\% operowanych, pozostałe $25 \%$ oceniło ból na 3 z 10 w skali VAS. Komponenta funkcjonalna skali AOFAS wykazała dobre ustawienie osiowe w stawie skokowym, minimalne ograniczenie aktywności i zaburzenia wzorca chodu oraz możliwość pokonywania długich dystansów.

Zabieg usztywnienia stawu skokowego i endoprotezoplastyka wiążą się z ryzykiem powikłań, zarówno w okresie pooperacyjnym, jak i odległym. W przypadku artrodezy oczywistą konsekwencją jest zniesienie ruchomości w stawie, co może prowadzić do zmian zwyrodnieniowych w okolicznych stawach stopy [25-27]. Główną obawą związaną z TAR jest zwiększone ryzyko aseptycznego obluzowania protezy, głębokie infekcje oraz powstawanie wyrośli kostnych. Wyższe ryzyko infekcji wiązane jest z seropozytywnością dla wirusa HIV i HCV [10], natomiast obluzowanie elementów protezy może wynikać z większego ryzyka mikrowylewów na powierzchni styku kości i implantu [22].

Głównym celem postępowania fizjoterapeutycznego jest przywrócenie możliwie najlepszej sprawności, szczególnie jak najbardziej zbliżonego do prawidłowego wzorca chodu. W literaturze brak jest doniesień na temat chodu $u$ chorych na hemofilię, u których przeprowadzono zabieg usztywnienia bądź alloplastykę stawu skokowego. Wydaje się, że w związku z coraz większą liczbą wykonywanych zabiegów TAR, tego rodzaju badania z zakresu biomechaniki, kinematyki i kinetyki powinny zostać przeprowadzone. W swoich badaniach Piriou i wsp. [28], Hahn i wsp. [29] oraz Flavin i wsp. [30] podejmują się porównania funkcji chodu w grupach pacjentów ze zmianami zwyrodnieniowymi, reumatycznymi i pourazowymi, poddanych zabiegowi artrodezy lub endoprotezy. Nie potwierdzili oni jednoznacznej przewagi jednej interwencji nad drugą, ponieważ poprawę uzyskano w zakresie różnych parametrów chodu, trudno więc uznać któryś z nich za mniej lub bardziej ważny. Żadna $\mathrm{z}$ grup nie osiągnęła zgodnego $\mathrm{z}$ prawidłowym wzorca chodu.

Fizjoterapeuta jest niezbędnym członkiem wielodyscyplinarnego zespołu specjalistów, sprawujących opiekę nad chorymi na hemofilię. Współpraca fizjoterapeuty z hematologiem jest warunkiem skutecznej i bezpiecznej rehabilitacji układu ruchu u chorych dotkniętych artropatią hemofilową. Rehabilitacja jest klasycznym wskazaniem do wdrożenia okresowej profilaktyki krwawień w schemacie zależnym głównie od ciężkości skazy krwotocznej oraz intensywności fizjoterapii.

\section{Wnioski}

1. Zastosowane leczenie fizjoterapeutyczne pozwoliło na uzyskanie poprawy w zakresie możliwości funkcjonalnych oraz bólu.

2. Uzyskana poprawa zakresu ruchomości była nieznaczna, co jednak jest zgodne $\mathrm{z}$ doniesieniami w literaturze.

3. W świetle uzyskanych wyników zabieg endoprotezoplastyki stawu skokowego u opisanego pacjenta okazał się korzystnym rozwiązaniem leczniczym.

\section{Wkład autorów/Authors' contributions}

KG - koncepcja pracy, zebranie i interpretacja danych, przygotowanie pracy, przygotowanie literatury. AZ, JZ interpretacja danych, przygotowanie literatury. WS - interpretacja danych.

\section{Konflikt interesu/Conflict of interest}

Nie występuje.

\section{Finansowanie/Financial support}

Nie występuje. 


\section{Etyka/Ethics}

Treści przedstawione $\mathrm{w}$ artykule są zgodne $\mathrm{z}$ zasadami Deklaracji Helsińskiej, dyrektywami EU oraz ujednoliconymi wymaganiami dla czasopism biomedycznych.

\section{PIŚMIEN N ICT W O/REFERENCES}

[1] Windyga J, Chojnowski K, Klukowska A, et al. Polskie zalecenia postępowania we wrodzonych skazach krwotocznych na tle niedoboru czynników krzepnięcia. Część I: Zasady postępowania w hemofilii A i B. Acta Haematol Pol 2008;39(3):537-564.

[2] Riva S, Bullinger M, Amann E, von Mackensen S. Content comparison of haemophilia specific patient-rated outcome measures with the international classification of functioning, disability and health (ICF, ICF-CY). Health Qual Life Outcomes 2010;8:139.

[3] Cuesta-Barriuso R, Gómez-Conesa A, López-Pina JA. Physiotherapy Treatment in Patients with Hemophilia and Chronic Ankle Arthropathy: A Systematic Review. Rehabil Res Pract 2013;2013:305249.

[4] Funk M, Schmidt H, Escuriola-Ettinghausen C, et al. Radiological and orthopedic score in pediatric hemophilic patients with early and late prophylaxis. Ann Hematol 1998;77(4):171-174.

[5] Luck JV, Lin JC, Kasper CK, Logan LJ. Orthopaedic management of haemophilic arthropathy. J Am Acad Orthop Surg 2004;12:234-235.

[6] Rodgriguez-Merchan EC. Orthopaedic Problems about the Ankle in Hemophilia. J Foot Ankle Surg 2012;51(6):772-776.

[7] Rodgriguez- Merchan EC. End-stage haemophilic arthropathy of the ankle: ankle fusion or total ankle replacement. Haemophilia 2014;20(1):106-107.

[8] Pasta G, Forsyth A, Merchan CR, et al. Orthopaedic management of haemophilia arthropathy of the ankle. Haemophilia 2008;14(Suppl 3):170-176.

[9] Carlsson AS, Montgomery F, Besjakov J. Arthrodesis of the ankle secondary to replacement. Foot Ankle Int 1998;19 (4):240-245.

[10] Strauss AC, Goldmann G, Wessling M, et al. Total ankle replacement in patients with haemophilia and virus infections - a safe alternative to ankle arthrodesis? Haemophilia 2014;20(5):702-708.

[11] Henne TD, Anderson JG. Total ankle arthroplasty: a historical perspective. Foot Ankle Clin 2002;7(4):695-702.

[12] http://www.aofas.org/footcaremd/treatments/Pages/TotalAnkle-Arthroplasty.aspx, wersja z dnia: 2.10.2014.

[13] Podsiadlo D, Richardson S. The Timed Up \& Go: a test of basic functional mobility for frail elderly persons. J Am Geriatr Soc 1991;39(2):142-148.
[14] Soucie JM, Cianfrini C, Janco RL, et al. Joint range-of-motion limitations among young males with hemophilia: prevalence and risk factors. Blood 2004;103(7):2467-2473.

[15] Narodowy Program Leczenia Chorych na Hemofilię i Pokrewne Skazy Krwotoczne na lata 2012-2018, Warszawa 26.09.2011, www.mz.gov.pl.

[16] Schuh R, Hofstaetter J, Krismer M, et al. Total ankle arthroplasty versus ankle arthrodesis. Comparison of sports, recreational activities and functional outcome. Int Orthop 2012;36(6):1207-1214.

[17] Barg A, Elsner A, Hefti D, Hintermann B. Haemophilic arthropathy of the ankle treated by total ankle replacement: a case series. Haemophilia 2010;16(4):647-655

[18] Gougoulias N, Khanna A, Maffulli N. How successful are current ankle replacements? A systematic review of the literature. Clin Orthop Relat Res 2010;468(1):199-208.

[19] Gamble JG, Bellah J, Rinsky LA, Glader B. Arthropathy of the ankle in hemophilia. J Bone Joint Surg Am 1991;73(7):10081015.

[20] Tsailas PG, Wiedel JD. Arthrodesis of the ankle and subtalar joints in patients with haemophilic arthropathy. Haemophilia 2010;16(5):822-831.

[21] Mann HA, Biring GS, Choudhury MZ, Lee CA, Goddard NJ. Ankle arthropathy in the haemophilic patient: a description of a novel ankle arthrodesis technique. Haemophilia 2009;15(2):458-463.

[22] Panotopoulos J, Hanslik-Schnabel B, Wanivenhaus A, Trieb K. Outcome of surgical concepts in haemophilic arthropathy of the hindfoot. Haemophilia 2005;11(5): 468-471.

[23] Rodriguez-Merchan EC. Ankle surgery in haemophilia with special emphasis on arthroscopic debridement. Haemophilia 2008;14(5):913-919.

[24] Bluth BE, Fong YJ, Houman JJ, Silva M, Luck Jr JV. Ankle fusion in patients with haemophilia. Haemophilia 2013;19 (3):432-437.

[25] Coester LM, Saltzman CL, Leupold J, Pontarelli W. Longterm results following ankle arthrodesis for post- traumatic arthritis. J Bone Surg Am 2001;83-A(2):219-228.

[26] Takakura Y, Tanaka Y, Sugimoto K, et al. Long-term results of arthrodesis for osteoarthritis of the ankle. Clin Orthop Relat Res 1999;361:178-185.

[27] Fuchs S, Sandman C, Skwara A, Chylarecki C. Quality of life 20 years after arthrodesis of the ankle. A study of adjacent joints. J Bone Surg Br 2003;85(7):994-998.

[28] Piriou P, Culpan P, Mullins M, et al. Ankle replacement versus arthrodesis: a comparative gait analysis study. Foot Ankle Int 2008;29(1):3-9.

[29] Hahn ME, Wright ES, Segal AD, Orendurff MS, Ledoux WR, Sangeorzan BJ. Comparative gait analysis of ankle arthrodesis and arthroplasty: initial findings of a prospective study. Foot Ankle Int 2012;33(4):282-289.

[30] Flavin R, Coleman S, Tenenbaum S, Brodsky J. Comparison of gait after Total Ankle Arthroplasty and Ankle Arthrodesis. Foot Ankle Int 2013;34(10):1340-1348. 